\title{
Research and Enlightenment of American Community College Curriculum System
}

\author{
Liu Yu \\ Research Institute of Higher Education, Guangdong Communication Polytechnic, Guangzhou, China \\ Email address: \\ 28312048@qq.com \\ To cite this article: \\ Liu Yu. Research and Enlightenment of American Community College Curriculum System. Teacher Education and Curriculum Studies. \\ Vol. 6, No. 1, 2021, pp. 33-40. doi: 10.11648/j.tecs.20210601.17
}

Received: March 11, 2021; Accepted: March 22, 2021; Published: March 30, 2021

\begin{abstract}
The relatively perfect curriculum system of American community colleges has laid a solid foundation for the technical talents and the smooth connection of general vocational integration. It has also trained a large number of highly skilled technical personnel for various communities in the United States. In order to promote the construction of an integrated curriculum system of vocational education in China, based on the analysis of the logic structure of the curriculum system of American community colleges, this paper summarizes the three characteristics of the system, which are "unity of freedom and flexibility, compatibility of academic and professional, and combination of cohesion and development". Analyze the dilemma of "loose architecture," "out of focus" and "low relevance of vocational and technical courses". Based on this, from the perspective of innovation and development, this paper explores the three trends of American community college curriculum system "adjust and update the course content; enhancing the effectiveness of developmental education programs; establish a unified certificate system and curriculum system" and some enlightenment of "pay attention to the effective connection of the curriculum system; strengthen the development of education and training courses; pay attention to the evaluation of course teaching quality;" for the construction of vocational education curriculum system in China.
\end{abstract}

Keywords: United States, Community College Curriculum System, Characteristic, Trouble

\section{Introduction}

American community colleges provide two-year education, which mainly includes three educational functions: transfer education, vocational education and community education. Their establishment aims to improve the educational level of the whole American people, promote the employment rate and the comprehensive competitiveness of the United States. As of 2018, there were 1,103 community colleges in the United States, with an enrollment of about 12.1 million students, accounting for $41 \%$ of all undergraduate students in the United States and below. [1] Community college plays a very important role in the structure of American higher education. There are many reasons for its success, among which the most important one is the accurate orientation of its school-running function and the establishment of a flexible, diversified and unique curriculum system that meets the requirements of regional economic development. However, in recent years, community colleges have also faced questions about student pressure, government funding and teaching quality. In terms of the curriculum system, too much attention is paid to the "buffet" mode of course selection, which leads to the loose structure of the curriculum and the low graduation rate and transfer rate. A comprehensive and in-depth study of the curriculum system of American community colleges is of great significance to the construction of the curriculum system of higher vocational education in China.

\section{The Logic Structure of American Community College Curriculum System}

Curriculum system refers to the order of different courses of the same major, which is the sum of the teaching content and 
process. The order of courses determines what kind of knowledge structure students will acquire through learning. The curriculum system is the guiding ideology of the education activities, the concretization and support of the training objectives, and it stipulates the planning scheme for the implementation of the training objectives. The curriculum system mainly consists of specific curriculum view, curriculum objective, curriculum content, curriculum structure and curriculum activity mode. [2] Therefore, in-depth analysis of the curriculum system can be discussed from its logical components.

\subsection{Course Objectives}

American community college courses are divided into general education curriculum system and professional curriculum system. According to the different objectives, the professional curriculum system is divided into degree curriculum system, graduation certificate curriculum system and qualification certificate curriculum system.

The goals of the general education curriculum system mainly focus on four aspects: communication, critical thinking, productive skills and personal responsibility and social responsibility. Minneapolis Community \& Technical College, for example, has a general education curriculum that encompasses 10 target areas: written and spoken communication, critical thinking, natural sciences, mathematical or logical thinking, history and sociology, human nature and aesthetics, human diversity, global perspective, ethical and civic responsibility, and people and the environment. [3] These areas cover virtually all areas of human development, with special emphasis on communication, fostering critical thinking, and fostering a sense of responsibility.

The goal of the professional curriculum system is that after systematic learning, students have acquired the knowledge and skills necessary for their career within a certain range. To be specific, it is mainly as follows: First, it is to prepare for higher and deeper learning; The second is to enable students to have the qualifications and skills required by a certain occupation or occupation group; The third is to increase students' knowledge and understanding of a particular field or subject. Under the guidance of this goal, each major combined with the occupation and post needs, to build their own professional curriculum system. [3]

\subsection{Course Structure}

The educational functions of American community colleges determine that their curriculum structure consists of three parts. The first is transfer education curriculum. Most students take the course in order to move on to a four-year university; Second, vocational and technical education courses. This course can be further divided into three categories, namely applied associate degree courses and certificate courses Program and short training courses. Third, compensatory courses. Students study the course in order to improve their knowledge or skill needs in a particular area.

\subsection{Curriculum Setting}

Associate degree courses in American community colleges are divided into transfer courses and applied courses, which are composed of general education courses and professional education courses, but there are certain differences. Most of the transfer associate's degree programs are credit courses, and students earn credits that are recognized by most colleges and universities in their state for the opportunity to continue their studies at a four-year university. The applied associate's general education program is the same as above, but the professional education program is different in that some credits are recognized by state colleges and some are not. Unrecognized courses are often closely related to employable skills.

Certificate courses have different courses for different certificates, but because certificate courses have a short time span and are mainly for the employment of learners, full-time students can usually complete all the courses within two semesters.

Compensatory programs are designed to equip learners to move on to associate's degree programs and are primarily taught to veterans and high school dropouts. The main contents of study are English, mathematics, social science and so on. Philadelphia Community College, for example, offers GED preparation. The program is actually for students who want to take the GED test. The school also offers elementary, intermediate and advanced English courses for students whose English is a second language. [4]

\subsection{Curriculum Quality}

American community colleges in the early stages of development have also been "unfair treatment", four-year college or university is often considered a secondary education, until the $1970 \mathrm{~s}$, is considered part of the higher education, but still failed to get rid of the label of "second-class citizens", in order to improve the status, community college has made unremitting efforts to ensure the quality of teaching in.

First of all, from the perspective of the whole quality control system, it can be divided into internal and external aspects. The internal system focuses on self-examination, self-investigation and self-improvement; The external system mainly supervises, reviews, participates, and formulates prescriptive and guiding policies. It can be seen that the internal system is based on the policies and suggestions of the external system, and the policies and guidelines of the external system are the product of the synthesis and summary of the practice of the internal system of the school. [5]

Specifically, the internal teaching quality assurance system has its own characteristics, gradually realizing the integration with the four-year universities, and students' achievements are recognized by the universities. The American higher education system attaches great importance to basic courses, and emphasizes the effect of basic courses when systematically designing courses. After students complete the study of basic courses, they will often be evaluated. The evaluation method is generally taken by examination, which can be designed or 
purchased by the school itself. This can also be a good control for the quality of students' learning effect. There are various methods in classroom teaching evaluation, the common methods include course paper, collective work, speech and so on. Adopt two-way assessment, students and teachers carry out comprehensive assessment on each other. In addition to classroom evaluation, professional courses are combined with course practice and graduate forum courses.

Among the external teaching quality, inviting external consultants to participate in the course design is the most characteristic external teaching quality monitoring measure of community colleges. For example, in the course design of computer application major, professionals from local industrial and commercial enterprises are invited to form an expert group with professors of our school to jointly design the course arrangement. [6] This ensures that the teaching of community colleges can reflect certain quality. Extracurricular assessment is also an important part, mainly through course practice and students' participation in off-campus activities.

\section{Characteristics of American Community College Curriculum System}

\subsection{Unity of Freedom and Flexibility}

The setting and organization of courses in American community colleges are characterized by flexibility and freedom, highlighting the arrangement of the "student-centered" curriculum system, which can better meet students' basic needs, entrance needs and lifelong learning.

The curriculum is flexible and varied. The community college in Peralta, for example, offers a large number of classes at various levels in English literacy, math and computer science. These courses are taught at different levels to ensure that students are able to communicate at a basic level. About 35 percent of Peralta's students transfer to a four-year college, which means that some of the community college's courses can meet transfer needs. [6] In addition, because this community is located in the east of the San Francisco Bay Area, the service industry and manufacturing industry are developed. Small, medium and large enterprises and the Port of Auckland have driven the local economy. Many famous enterprises have their headquarters in this area. Therefore, the basic education courses and other courses of Peralta Community College have different focuses, and set up specialized courses combining with the community economy. Such as Laney College's architectural engineering, bionic manufacturing, environmental control technology, mechanical technology, carpentry, cooking and makeup, etc. Berkeley City College has strong competitiveness in biology and biotechnology, computer information systems, multimedia arts, business, chemistry and other majors. Merritt College is featured in health care and bioscience, environmental sustainability management and technology, cyber security, landscape gardening, environmental management, child development, etc. The specialties of Alameda College include Dental Education and Dental Assistant, Aviation Maintenance Project, Automobile Automation Technology, etc. The Dental Education and Dental Assistant program is certified by the American Dental Association, the Aviation Maintenance Program is certified by the Federal Aviation Administration, and the Automobile Maintenance Program is certified by the National Institute of Automotive Quality Service. [7]

In terms of course schedule, day and night are offered alternately, and most students work during the day and attend classes at night. In addition, the course resources are also very rich, almost all of the courses have set up online courses, important learning materials and homework can be obtained from the Internet, and it also provides convenience for students who can't go to school.

Students learn by themselves, generally speaking, through discussion, cooperation and group work. The teaching methods of teachers are flexible. Different teachers and different courses have certain differences in learning and organization forms.

\subsection{Academic and Professional Compatibility}

"Transfer and employment" is the most important function of American community colleges. The two are not only different from each other but also interrelated, which is not as obvious as the division in the curriculum. Instead, the curriculum reflects the characteristics of both academic and professional.

In order to be able to connect with the courses of the senior year of the four-year university, transfer courses must reflect a strong academic nature, and the characteristics of the systematic and logical development of knowledge structure must be reflected in these courses. The employment function lies in the vocational courses offered by the community college, which aims to promote students' better employment. However, vocational education programs at community colleges are not designed entirely for occupations and job groups. For example, in addition to vocational courses, academic courses also account for a certain proportion of professional education courses offered by a major in a community college. The main reason for this is that it is difficult to distinguish the two types of courses in a strict sense. In addition, as the subject of education, students who enter a professional field of study sometimes do not have a very clear goal for transfer or employment, and they will gradually clarify their direction in the middle of the course. Therefore, the early differentiation of courses will also bring some influence on the development of students. In fact, the curriculum system of academic and professional compatibility is not contradictory. To some extent, it also reflects the idea advocated by the new vocationalism -- to attach importance to academic education in the process of offering vocational education courses. This can be seen, for example, in the curriculum of Maine's building technology majors. 
Table 1. Middle Maine Community College Building Construction Technology Course Schedule.

\begin{tabular}{|c|c|c|}
\hline Term course & course name and credit & Course tendency judgment \\
\hline \multirow{6}{*}{ Semester 1} & introduction to hand and power tool safety ( 1 credit) & occupational \\
\hline & Architectural Concepts I ( 3 credits $)$ & Academic \\
\hline & Architectural Concepts ( 3 credits) & Academic \\
\hline & Construction Site Supervision (2 credits) & occupational \\
\hline & Intermediate Algebra (3 units) & Academic \\
\hline & Fundamentals of Building Safety and Health (3 credits) & Academic, occupational \\
\hline \multirow{5}{*}{ Semester 2} & Fundamentals of Materials Mechanics ( 2 credits) & Academic \\
\hline & Academic building concept III (3 credits) & Academic \\
\hline & Academic building concept IV (3 credits) & Academic \\
\hline & Fundamentals of Building Science ( 3 credits) & Academic \\
\hline & Geometry and Trigonometry (3 units) & Academic \\
\hline \multirow{6}{*}{ Semester 3} & Fundamentals of Computer Application ( 3 credits) & Academic, occupational \\
\hline & Construction Appraisal (3 credits) & Academic, occupational \\
\hline & Interior Decoration ( 2 credits $)$ & occupational \\
\hline & College Writing ( 3 credits) or College Writing Seminar ( 4 credits) & Academic \\
\hline & Electives: Humanities/Social Sciences ( 3 credits) & Academic \\
\hline & Electives: Mathematics/Science (3-4 credits) & Academic \\
\hline \multirow{6}{*}{ Semester 4} & Semester 4 Showcase ( 2 credits) & occupational \\
\hline & Finished Stairs ( 2 credits $)$ & occupational \\
\hline & Masonry ( 2 credits) & occupational \\
\hline & Technical Writing ( 3 credits) & occupational \\
\hline & Elective: Humanities ( 3 credits) & Academic \\
\hline & Elective: Social Sciences (3 credits) & Academic \\
\hline
\end{tabular}

\subsection{Both Cohesion and Development}

Connectivity is defined primarily by the seamless integration of community college courses with high school and four-year college courses. Specifically, the connection with high school courses means that some courses set by the community college are optional for students of the local high school, and the credits obtained can be recognized by the community college and the local high school. On the one hand, these courses can reduce the cost of learning for some high school students, and on the other hand, they can lay a foundation for their education in community colleges. These courses are also part of an associate's degree or certificate program at a community college effectively shortening their time at the community college. But this is the result of negotiations between some community colleges and their local high schools, not all of them. A link to a four-year university is an agreement between a transfer associate's degree program at a community college and a local four-year university to allow students to move on to the university after graduation so that they can adapt to the four-year university's curriculum as quickly as possible. Because transfer associate's degrees are the norm at community colleges, four-year colleges are eager to connect with them because of the student pool. But in general, connections between community colleges and four-year universities are most common within the state, with fewer and more difficult to implement across state lines.

Development is mainly for students' personal development and career development. Personal development mainly refers to the ability of students to further their studies after learning basic education courses, which also lays a foundation for their future employment. The United States is a country that pays attention to students' basic knowledge and basic ability. Therefore, each community college has set up a variety of basic courses, which provides students with a variety of choice opportunities and promotes the diversified development of students. Career development mainly refers to the college's vocational courses that prepare students for rapid and high quality employment in the community. As mentioned earlier, community colleges also offer many of these programs, in the form of short training programs, certificate programs, and applied associate's degrees, which are "a la carte" oriented toward the people needed in the community. Examples include education, health care and hotel management.

\section{Problems in the Curriculum System of American Community Colleges}

\subsection{Loose Architecture and Target "Out of Focus"}

Because American community colleges provide students with too much freedom in course selection, on the one hand, it reflects its democratic and free characteristics, but on the other hand, it also leads to the lack of effective guidance in course selection, the goal of "out of focus" and low learning effect.

Specifically, community college students on the course content, quantity and the corresponding program has the absolute option, "most of the students from the 60 academic and application field, more than 70 associate degree or certificate program, select the", [7] community college courses in each project usually don't close, more loosely, the lack of logic, it also causes the student to study the adverse effect; Students end up choosing courses to meet the requirements of the program, rather than acquiring the 
relevant knowledge and skills that are consistent with the goals and requirements. In addition, the course of credit transfer has not been completely connected. According to statistics, more than 80 percent of first-time community college students hope to move on to a four-year college and earn a degree. But only about 40 percent earn a degree in five years, and more than 60 percent take six years to earn a bachelor's degree. [8] The key reason for this low graduation rate and high delay rate is the lack of smooth connection between courses and universities. The main performance in two points, one is credit mutual recognition is not free. Because students cannot get effective guidance, they can only choose blindly, and most students choose "general education courses". Although the government has issued policies to guarantee credit transfer between general education courses and courses in four-year universities, not all majors in four-year courses in universities and many specific majors cannot be recognized, and specific majors have their own standards for recognition. Second, the mismatch of learning styles. Students are not required to choose majors immediately after they enter a community college, and they do not receive professional knowledge and training in time. Even after they enter a four-year university, it is difficult for them to adapt and it takes some time to adjust, which wastes a certain amount of time and energy.

\subsection{The Vocational and Technical Courses Are Not Highly Relevant}

It is mainly manifested in two aspects. One is the insufficient coverage of vocational knowledge and skills in the design of vocational technical courses. Second, the pertinence is not strong. To be specific, insufficient coverage means that the knowledge required for a specific career in the future is not fully covered, but only part of it. After graduation, students still need to continue to participate in training and practice to acquire comprehensive knowledge and master most of the required skills. The lack of pertinence mainly means that the curriculum design fails to closely follow the skill requirements of the post. Although students have learned relevant knowledge and skills, the most important knowledge and skills of the post are not included. There are two reasons for this. First, students study for a short time, not enough time to master more comprehensive knowledge and technology; In addition, the resources that community colleges can provide are limited, for example, the knowledge coverage and timeliness of the teaching materials also have a certain impact. Secondly, the limitation of curriculum designers' ability also leads to this situation.

\section{The Development Trend of American Community College Curriculum System}

\subsection{Adjust and Update the Course Content}

From the macro level, with the development of national economy, industrial transformation and upgrading put forward higher requirements for talent cultivation of vocational and technical education, which also means that community colleges should pay attention to the adjustment of course structure and content in the process of talent cultivation. From the middle level, American states or communities should also make predictions and judgments when facing regional industrial structure changes and adjustments, so as to timely understand the changes in vocational knowledge and skills brought about by industrial changes, so as to adjust and update curriculum Settings and contents. From the micro level, the education and training programs of community colleges, especially the curriculum design, content and implementation methods, should adapt to the rapid changes of industrial upgrading speed and industrial transfer frequency. Such challenges also require community colleges to continuously improve the curriculum design, update the content and integrate teaching resources.

\subsection{To Enhance the Effectiveness of Developmental Education Courses}

In order to reform the developmental education courses of community colleges, many states in the United States have enacted laws to cancel the requirements of students' developmental courses, actively improve these introductory courses, and set up "transitional courses" by contacting with the community high schools in the state. The Center for the Study of Community Colleges (CCRC) counts high schools in Columbia and Florida as examples of transitional curriculum reform. These courses not only include online and offline courses, but also adopt the mode of joint development, and the main body of development is high school and university teachers. Establish common developmental curriculum objective content and sequence and evaluation criteria in the course of curriculum development. If high school students get low marks in a certain course, they can choose to take the corresponding transitional courses, which not only gain credits, but also cultivate the ability to complete college courses. Practice shows that the earlier such measures are taken, the better the effect is. Some scholars suggest that K-12 education in the United States should be linked with college education, so that college curriculum should be integrated with the design of primary and secondary school curriculum.

Some community colleges in the United States have tried to classify developmental courses for students. For example, 50 community colleges in Texas, working with the Center for Education Research, have redesigned math requirements for students in different majors. For students who do not plan to pursue science, technology, engineering or math, the requirement to take an algebra course has been removed and courses such as statistics or reasoning based on their future major needs." [9] Students are assessed on their abilities and development direction to determine which development courses are available to them. This assessment method can not only enable students to understand the needs of community colleges, but also help students to choose suitable developmental courses. This approach has changed the 
previous idea of taking developmental courses as the threshold and has truly served the students.

\subsection{Establish a Unified Certificate System and Curriculum System}

Walter Bumphus, president of the American Association of Community Colleges, has written that the future direction for community colleges is to establish a system of cohesive certificates and national certificates. [10] Although we have a good foundation to establish a unified certificate and curriculum system, we still face great difficulties. In order to overcome the difficulties, efforts should be made from the government, the society and the college itself.

From the perspective of government departments, the government will take active and effective measures to guide community colleges and industries to develop courses and promote the formation of unified standards. It is mainly manifested in two aspects: one is to promote the integration of unified standards through research; On the other hand, the cooperation between industry and university is promoted through project funding.

From the point of view of certification authorities, there is a need for unified integration. Current U.S. professional certificate issuing authority is more complex, there are national industry association also have local industry association, association of influential can nationwide unified the entry standard of one kind of occupation, but there are just some of the professional qualification certificate in states, the curriculum design are different due to different criteria, so community college curriculum is inaccurate positioning of knowledge skills. If the awarding agencies can unify the standards across the country, then the curriculum or the development of textbooks can be unified, and the standards can be unified, and the above-mentioned problems will not appear.

From the perspective of community colleges, they should try their best to integrate subject courses and vocational courses. Higher Education in the United States

As a result, the subject and curriculum system of community colleges has been improved. However, the vocational certificate curriculum system is not easy to be improved due to the rapid change of occupation and the updating of knowledge and technology. Many courses in community colleges are built on the basis of subject courses, showing the characteristics of "subject courses + vocational courses". This makes the curriculum system is insufficient and the coverage of vocational courses is limited. Therefore, it is urgent to establish a unified curriculum system and certificate system.

\subsection{Development of Curriculum System from "Buffet" to Project Path}

In order to provide American community college students with both free choice and guidance in the choice of courses, and effectively improve the efficiency of students' learning outcomes, the government has carried out a structural reform, adopting "active choice" + "default option". [11] The "default option" refers to the fact that the project chosen by the student is a combination of several courses that have been designed by experienced teachers across departments or even across schools, and that the combination is scientific and practical. However, students' single choice of such combined courses limits their interests and other development to some extent. Therefore, they can also carry out "active choice" of courses. These actively selected courses can enable students to understand the corresponding majors from the major categories, and choose specific majors in the major categories. For example, in the first semester, students first choose a field of study, including social services, science, arts, and health. [12] In the middle of these areas, students can learn some basic knowledge and skills, and if students are interested, they can go on to further study in specific projects in this area. These projects have a default curriculum that has been put together.

\section{Enlightenment of Curriculum System Construction of Higher Vocational Education in China}

\subsection{Pay Attention to the Effective Connection of the Curriculum System}

The effective connection between the curriculum system of American community colleges and high schools and four-year universities is worthy of reference for higher vocational education in China. First of all, in terms of the framework of the system,

First, if the entrance channel between vocational colleges and vocational colleges or ordinary undergraduate colleges can be opened, qualified vocational college students can be promoted to undergraduate colleges and universities to obtain the opportunity for further study. At present, China has started the practice of the long schooling system and "4+0" and "Upgrade to Primary Education", but it is not widespread, the channels are not smooth, and the number of students is still relatively limited. Second, the cohesion between secondary vocational schools and vocational colleges curriculum system should be further expand, although higher vocational large-scale enrollment expansion in recent years, millions each year in enrollment, students mainly comes from the secondary vocational students, but is still in the exploratory stage, to gradually develop large area, also need to study practice, one of the most important thing is to get through the channels of class cohesion. Third, we can explore the possibility of offering courses for credits recognized by higher vocational colleges in secondary vocational colleges, so as to help them gain time to study in higher vocational colleges and reduce some costs. In the course content to do a good job in the convergence of accommodation. Knowledge and skills have a certain development law and logical structure, so the arrangement of course content must follow a certain order. The integration of course content is to straightened out the logical relationship between knowledge and knowledge, 
knowledge and skills of different levels and majors, so that students can learn more smoothly in the cross-major and cross-level learning process.

\subsection{Strengthen the Development of Education and Training Courses}

At present, the training function of higher vocational education in our country has not been fully played, which is mainly carried out in academic education. Therefore, we can learn from the education and training function of American community colleges and expand the training function by adding courses.

Specifically, the development of regional and industry-oriented education and training courses and self-development courses can be explored. The training courses are mainly opened for the units with training needs, and also for the groups who need to improve their ability and technical level.

From the perspective of resources, higher vocational colleges can organize relevant teachers and technical personnel to develop practical textbooks for use in the development of education and training courses. The shortage of trained teachers can be solved by hiring part-time teachers. In addition, effective integration of resources and training can be carried out through cooperation with enterprises. In short, higher vocational colleges should actively explore and develop their own training functions, face the market demand, rely on the market for the integration of resources, so as to make higher vocational colleges become regional or industrial education and training hub.

\subsection{Pay Attention to the Evaluation of Course Teaching Quality}

The first is to evaluate the implementation process. The original data can be analyzed on the basis of mathematical statistical modeling to determine the score value of the evaluation subject in the evaluation system. In the process of statistical analysis, attention should be paid to the combination of qualitative and quantitative methods, so as to eliminate the deviation caused by some subjective factors, such as relationship, preference and knowledge level, in the evaluation process of students, supervisors and peers to the greatest extent, and improve the quality of evaluation activities. Specifically, the tripartite evaluation should determine the weight of the subject in the evaluation system, and should not attach too much importance to any party, with percentages of $30 \%, 30 \%$ and $40 \%$ respectively. In addition, a comparative method can be used for rating. Firstly, the evaluation results can be evaluated according to excellent, good, qualified and unqualified by qualitative analysis. Secondly, peers and supervisors should also refer to the evaluation of second-level teaching units for comparison, and finally determine the evaluation level.

Reform should be carried out in the way of evaluating calculation methods. Teachers' evaluation scores can be calculated on an annual basis. The results of supervision evaluation and peer evaluation are calculated and submitted by the second-level teaching unit and the supervision committee, and the final evaluation results of teachers are obtained. The student evaluation is organized by the Academic Affairs Office according to the course arrangement for many times, and the average value is taken as the teacher's student evaluation result of that year.

The feedback of the evaluation structure and the establishment of the corresponding incentive mechanism. Peers and supervisors are operable when giving feedback. They feed back the information to the teacher in time and input the results of the current class attendance into the system. According to the records of repeated class attendance, they make the final evaluation on whether the teacher's teaching methods are improved or optimized. The second class attendance for the lower 5\% of teachers can help them improve their teaching quality.

\section{Conclusion}

In a word, the construction of the curriculum system of American community colleges not only reflects the characteristics of vocational education, but also makes it more smoothly connected with general education, forming a relatively rigorous "curriculum network". With the development of the new era, although the curriculum system of community colleges in the United States has also encountered a series of problems mentioned above, the timely corrective policies of the federal government and the strict implementation of state governments have ensured the good development trend of the curriculum system of community colleges. China's vocational education system has been initially established, but the connection is still not smooth enough, which is reflected in the construction of the curriculum system, which has obvious hierarchical boundaries, and the realization of an integrated curriculum system is faced with numerous difficulties. An in-depth analysis of the construction characteristics and development trend of the curriculum system of American community colleges is of great significance for the development of China's vocational education curriculum system and integrated vocational education.

\section{Foundation Project}

Guangdong Provincial Education Science "13th Five-Year Plan" 2020 Annual Research Project "Research on the Construction of Curriculum System of High-level Specialty Group in Higher Vocational Colleges under the Background of" Double High School Plan "(No.: 2020GXJK591, Host: Liu $\mathrm{Yu})$.

\section{References}

[1] AACC. Fast Facts 2018 [DB/OL]. (2018-04) [2018-05-05]. https://www.aacc.nche.edu/wp-content/uploads/2018/04/2018Fast-Facts.pdf. 
[2] https://zhidao.baidu.com/question/312601238.html.

[3] GAO HAI XIA. Diversity and Human Nature: Curriculum Characteristics of American Community Colleges [J]. Modern Educational Management, 2010 (8): 116-119. (in Chinese).

[4] Peng Yue gang. Research on the Development and Change of American Community College [D], East China Normal University, 2017, p85.

[5] Shi Qiu heng, Ning Bin. The Structure and Design Thought of Teaching Quality Monitoring System in American Community College [J]. Research in Higher Education, 2006 (8): 91-96.

[6] Li Jin-chao, Wu Yong. "Student-centered" Education Idea in American Community Colleges [J]. Higher Education Development and Evaluation, 2019, 35 (04): 97.

[7] Judith Scott-Clayton. The shapeless river: Does a lack of structure inhibit students' progress at community colleges? [EB/OL]. (2011-01) [2018-01-07]. https://ccrc.tc.columbia.edu/media/k2/attach ments/shapeless-river.pdf.
[8] Mary Ziskin, Yi-Chen Chiang, Jin Chen, Autumn Harrell, Vasti Torres. Baccalaureate attainment: Outcomes of students who transfer from two- year to four- year institutions [EB/OL].(2013-08-06) [2018-01-07]. https://nscresearchcenter.org/wp-content/uploads/SignatureRe port5.pdf.

[9] Lian Jinjun, Yang Minmin. The difficulties in the development of American community colleges, the reform trend and its enlightenment [J]. Jiangsu Higher Education, 2019 (2): 106-112.

[10] BUMPHUS W. The next big things [J]. Community College Journal. April /May 2014, 84 (5): 14.112.

[11] Li Zheng, Xu Guoqing. Guidance Path Project: Deep Reform of American Community Colleges [J]. Foreign Educational Research, 2019, 46 (06): 17-29.

[12] Jenkins, D., Cho, S.-W. Get With the Program ... and Finish It: Building Guided Pathways to Accelerate Student Completion [J]. New Directions for Community Colleges, 2013, (164): 27-35. 